\title{
Electronic Evidence in Criminal Procedural Law
}

\author{
Dian Eka Kusuma Wardani ${ }^{1}$ Slamet Sampurno Soewondo ${ }^{2}$ Judhariksawan $^{2}$ \\ Abdul Maasba Magassing ${ }^{2}$ \\ 1.Doctoral Student, Faculty of Law, Hasanuddin University, Indonesia \\ 2. Professor of Law, Faculty of Law, Hasanuddin University, Indonesia
}

\begin{abstract}
The development of technology and information encourages law enforcement officials to be able to maximize case handling, such as investigations by utilizing electronic evidence. Electronic evidence has its own uniqueness, which is different from other general evidence such as objects that can be seen with the naked eye and the touch. Since the promulgation of Law No. 11 0f 2008 (ITE Law), there is an expansion of the types of evidence at court, namely electronic information and / or electronic documents. This research is a normative study using a statutory approach. The legal materials used are primary and secondary legal materials. Based on the results of this study that based on the provisions of the Marketplace 183 KUHAP, it can be concluded that the Criminal Procedure Code adheres to a negative law-based proof system and based on Article 5 paragraph (1) and paragraph (2) of the ITE Law that Electronic Information and / or Electronic / or the printout is valid legal evidence.
\end{abstract}

Keywords: Electronic Evidence, Evidence Systems, Evidence Tools.

DOI: $10.7176 / \mathrm{JLPG} / 104-01$

Publication date: December $31^{\text {st }} 2020$

\section{A. Introduction}

National development is a continuous process that must always be responsive to the various dynamics that occur in society. The rapid development and advancement of information technology has led to changes in the activities of human life in various fields which have directly influenced the birth of new forms of legal action. The use and utilization of information technology must continue to be developed to maintain, maintain and strengthen national unity and integrity based on laws and regulations in the national interest. ${ }^{1}$

The presence of Information and Communication Technology (ICT) provides convenience and excellent benefits to humans as users, namely to help solve problems in activities from simple to complex levels of difficulty, this is to achieve effectiveness and efficiency in every activity by solving problems, especially in information and communication. $^{2}$

The rapid development of information and communication technology has changed the behavior of society and human civilization globally. In addition, the development of information technology has caused the world to be borderless and caused significant social change to take place quickly. ${ }^{3}$ Information technology is currently a double-edged sword, because in addition to contributing to the improvement of welfare, progress and human civilization, it is also an effective means of acts against the law. ${ }^{4}$ Because of these acts against the law, the scope of the law is expanded to cover these acts..$^{5}$

Currently, a new legal regime has been born, known as cyber law or telematics law. Cyber law is internationally used for legal terms related to the use of information and communication technology. Likewise, the law of telematics is the embodiment of the convergence of telecommunications law, media law and informatics law. Other terms that are also used are law of information technology, virtual world law, and mayantara law. These terms were born considering the activities carried out through computer system networks and communication systems both locally and globally (internet) by utilizing computer system-based information technology which is an electronic system that can be seen virtually. Legal problems that are often faced are when it comes to the delivery of information, communication and / or transactions electronically, especially in terms of evidence and matters related to legal acts carried out through electronic systems. ${ }^{6}$ With regard to proof, in the Criminal Procedure Code (KUHAP) which regulates the procedures for criminal proceedings in court. It is not explained in depth with regard to the context of evidence, it's just that in the Criminal Procedure Code there is article 183 which regulates that judges may not impose a sentence on a person unless it is found that at least 2 (two) pieces of evidence are valid and therefore the judge is convinced that a criminal act actually happened and that the defendant

\footnotetext{
${ }^{1}$ Syamsir, S., \& Yetniwati, Y. (2019). Prospek Cyber Notary Sebagai Media Penyimpanan Pendukung Menuju Profesionalisme Notaris. Recital Review, 1(2), 132-146.

${ }^{2}$ Kadir, N. K., Judhariksawan, J., \& Maskun, M. (2019). Terrorism and cyberspace: A phenomenon of cyber-terrorism as transnational crimes. FIAT JUSTISIA: Jurnal Ilmu Hukum, 13(4), 333-344.

${ }^{3}$ Nur, R., Dharmawati, D., Bakhtiar, H. S., \& Siliwadi, D. N. (2020). Insult and Defamation through Information Technology: Indonesia Perspective. International Journal on Emerging Technologies, 11(4), 373-378.

${ }^{4}$ Raharjo, A. (2002). Cybercrime: Pemahaman dan upaya pencegahan kejahatan berteknologi. Bandung: Citra Aditya Bakti.

${ }^{5}$ Mansyur, D. M. A., \& Gultom, E. (2005). Cyber Law dan HAKI dalam Sistem Hukum Indonesia. Bandung: Refika Aditama.

${ }^{6}$ Elucidation of Law No. 19 of 2016 on Amendments to Law No.11 of 2008.
} 
was guilty of doing it.

The development of technology and information encourages law enforcement officials to be able to maximize case handling, such as investigations using electronic evidence. Electronic evidence has its own uniqueness, which is different from other general evidence such as objects that can be seen with the naked eye and touched. Since the promulgation of Law No. 11 of 2008 (ITE Law), there is an expansion of the types of evidence at court, namely electronic information and / or electronic documents.

With the enactment of Law No. 11 of 2008, can become a legal umbrella for the community, in terms of the implementation of proof of this Article, we really have to be careful, lest this become a gap for arrogant parties to make this Article as a rubber Article. In Article 27 paragraph (3) the ITE Law is viewed more broadly, not only in black and white through the ITE Law and the Criminal Code, but must be comprehensive and not partial. ${ }^{1}$

Based on this explanation, this article will discuss what is the proof system adopted by the Criminal Procedure Code and what is the legal force of electronic evidence in criminal procedural law.This research is a normative research with a conceptual approach and a statute approach. The legal materials used are primary legal materials obtained from indirect observation through internet media and secondary legal materials obtained from library materials.

\section{B. Analysis and Discussion}

1. The system of proof in the criminal procedural law

Proof is the central point of examination of criminal cases in court proceedings. In other words, in the evidence, there are provisions which contain outlines and guidelines on the methods or procedures justified by law in proving the guilt charged against the accused. ${ }^{2}$ Evidence law is a part of criminal procedural law which regulates various types of evidence which are valid according to law, the system adopted in evidence, the requirements and procedures for submitting evidence and the judge's authority to accept, reject and evaluate evidence. ${ }^{3}$

The types of proof according to the criminal procedural law:

a) Conviction in Time

Conviction in Time's proof system, determining whether a defendant is guilty is solely determined by the judge's judgment or the judge's conviction. this system gave judges too much freedom, making it difficult to monitor them. In addition, defendants or legal advisors find it difficult to defend. In this case the judge can sentence the Defendant, based on his belief that he has committed a mistake. ${ }^{4}$ The judge may take conviction and conclude from the evidence presented in court. The judge ignored the results of the examination of evidence and immediately withdrew conviction from the defendant's testimony or the defendant's confession. ${ }^{5}$

b) Convictio-Raisonee

This system is slightly more advanced than the first system. Even though the two systems, in terms of drawing up the results of the evidence, are still based on the judge's conviction, ${ }^{6}$ however, in this system, the judge's belief factor is "limited" because the judge's conviction must be supported by "clear reasons". The judge is obliged to describe and explain the reasons for his belief in the defendant's guilt. This belief must have logical grounds and be completely reasonable. ${ }^{7}$ This system of proof is divided into two parts, the first is proof based on the judge's conviction for logical reasons and the second is a theory of proof based on a negative law. ${ }^{8}$ What is meant in this case is, even though the law regulates the means of evidence, in terms of using them and placing the strength of the evidence tools it is up to the judge's consideration in forming his conviction, as long as the reasons used are logical. ${ }^{9}$

c) Evidence according to the law positively (Positief Wettelijk Bewijstheorie)

This system is guided by the principle of proof by means of evidence determined by law. To prove guilt or not, the Defendant was relying solely on valid evidence. ${ }^{10}$ This theory of proof which is based on positive Law seeks to get rid of all subjective considerations of the judge and bind the judge strictly according to the strict rules of evidence. ${ }^{11}$ This system really requires the judge to be obliged to find and find the truth of

\footnotetext{
${ }^{1}$ Andi Tenriajeng Papada, Muhammad Said Karim, and Wiwie Heryani. (2020). Kedudukan Alat Bukti Yang Diperoleh Melalui Teknologi Informasi Dalam Pembuktian Tindak Pidana Informasi Dan Transaksi Elektronik."Jurnal Al-Qadau: Peradilan dan Hukum Keluarga Islam. 7 (1). 107-118

${ }^{2}$ Manope, I. J. (2017). Kekuatan Alat Bukti Surat Elektronik dalam Pemeriksaan Perkara Pidana. Lex Crimen, 6(2).

${ }^{3}$ Sasangka, H., \& Rosita, L. (2003). Hukum pembuktian dalam perkara pidana: untuk mahasiswa dan praktisi. Bandung: Mandar Maju. p.10

${ }^{4}$ Hamzah, A. (2008). Hukum Acara Pidana Indonesia. Jakarta: Sinar Grafika. p. 252

${ }^{5}$ Harahap, M. Y. (2000). Pembahasan Permasalahan dan Penerapan KUHAP: Pemeriksaan Sidang Pengadilan. Banding, Kasasi, Peninjaun Kembali, Edisi Kedua, Jakarta: Sinar Grafika.

${ }^{6}$ Chazawi, A. (2006). Hukum pembuktian tindak pidana korupsi: UU no. 31 tahun 1999 diubah dengan UU no. 20 tahun 2001. Bandung: Alumni. p.26

${ }^{7}$ Harahap, M. Y. Op.Cit. p.278

${ }^{8}$ Hamzah, A. Op.Cit. p. 253

${ }^{9}$ Chazawi, A. Loc. Cit.

${ }^{10}$ Harahap, M. Y. Loc.Cit.

${ }^{11}$ Hamzah, A. Op.Cit. p. 25
} 
whether or not the Defendant is wrong in accordance with the procedures of evidence by means of evidence stipulated by law. ${ }^{1}$

d) Evidence according to the law negatively (Negatief Wettelijk Stelsel)

In a system of proof according to the Law which negatively has a formula, whether or not a Defendant is wrong is determined by the judge's conviction based on methods and by means of evidence that are valid according to law. ${ }^{2}$ Based on this formulation, a new Defendant can be found guilty if the guilt accused to him can be proven by means of evidence which is valid according to the law and at the same time the proof of that error is accompanied by the conviction of the judge. ${ }^{3}$

On the basis of the provisions of Article 183 of the Criminal Procedure Code, it can be concluded that the Criminal Procedure Code adheres to a system of proof according to law negatively. This means that in the case of evidence, research must be carried out, whether the defendant has sufficient grounds that are supported by means of evidence determined by law (at least two pieces of evidence) and if he is sufficient, then it is questioned whether or not the judge's belief in the defendant's guilt. Judging from the common practice of proceedings in Indonesian courts, namely efforts to prove each party by presenting various kinds of evidence along with the judge's conviction of an error based on the evidence. ${ }^{4}$ Apart from that, in Article 294 HIR which contains, no sentence will be sentenced to anyone if the judge is not sure of the defendant's guilt by means of evidence according to the law that it is true that a criminal act has occurred and that the accused has committed the act.

2. The force of law against electronic evidence in criminal procedural law.

Law No.19 of 2016 on amendments to Law No. 11 of 2008 (ITE Law) provides a legal basis regarding the legal strength of electronic evidence and the formal and material requirements for electronic evidence to be accepted in court.

Electronic Information and / or Electronic Documents and / or printouts thereof are valid legal evidence and is an extension of valid evidence in accordance with the applicable procedural law in Indonesia.

Electronic Information is one or a set of electronic data, including but not limited to writing, sound, images, maps, designs, photographs, electronic data interchange (EDI), electronic mail, telegram, telex, telecopy or the like, letters, signs, numbers, Processed access codes, symbols, or perforations that have meaning or can be understood by those who are able to understand them whereas Electronic Documents are any Electronic Information that is created, forwarded, sent, received, or stored in analog, digital, electromagnetic, optical, or the like, which can be seen, displayed and / or heard through a computer or electronic system, including but not limited to writing, sound, pictures, maps, designs, photographs or the like, letters, signs, numbers, Access Codes, symbols or perforations which have meaning or meaning or can be understood by those who are able to understand them. Between electronic information and electronic documents, both can be distinguished but cannot be separated. Both become digital evidence and printed results of electronic information and electronic documents will become documentary evidence. ${ }^{5}$

In the explanation above, it is said that electronic information and electronic documents as well as printouts are an extension of legal evidence in accordance with the applicable Criminal Procedure Law in Indonesia. What is meant by expansion here must be related to the types of evidence provided for in Article 5 paragraph (1) of the ITE Law. The expansion in question is: ${ }^{6}$

1) Adding evidence that has been regulated in criminal procedural law in Indonesia, for example the Criminal Procedure Code. Electronic Information and / or Electronic Documents as Electronic Evidence adds to the types of evidence regulated in the Criminal Procedure Code;

2) Expanding the scope of evidence that has been regulated in criminal procedural law in Indonesia, for example in the Criminal Procedure Code. The printout of Electronic Information or Documents is documentary evidence regulated in the Criminal Procedure Code.

The expansion of evidence provided for in the Criminal Procedure Code has actually been regulated in a number of scattered laws. For example the Company Documents Law, the Terrorism Law, the Corruption Eradication Law, the Money Laundering Law. The ITE Law emphasizes that in all applicable procedural laws in Indonesia, Electronic Information and Documents and their printouts can be used as legal evidence. ${ }^{7}$

According to R. Atang Ranomiharjo, evidence is tools that are related to a criminal act, these tools can be used as evidence, in order to create conviction for the judge, on the truth of a criminal act that has been committed by the Defendant. ${ }^{8}$ Regarding legal evidence in criminal procedural law, of course we refer to Article 184

\footnotetext{
${ }^{1}$ Harahap, M. Y. Loc.Cit

${ }^{2}$ Harahap, M. Y. Op.Cit. p.279

${ }^{3}$ Ibid.

${ }^{4}$ Imron, A., \& Iqbal, M. (2019). Hukum Pembuktian. Tanggerang: Unpam Press. p.6

${ }^{5} \mathrm{https}$ //www.hukumonline.com/klinik/detail/ulasan/cl5461/syarat-dan-kekuatan-hukum-alat-bukti-elektronik/ accessed on September 5, 2020

${ }^{6}$ Sitompul, J. (2012). Cyberspace, cybercrimes, cyberlaw: tinjauan aspek hukum pidana. Jakarta: PT Tatanusa.

Ibid.

${ }^{8}$ Darwan, P. (1989). Hukum Acara Pidana suatu pengantar. Jakarta: Djambatan. p.107
} 
paragraph (1) of Law No. 8 of 1981, as follows: ${ }^{1}$

a. statement by witnesses;

b. statement by experts;

c. document;

d. clues;

e. statement by defendants;

The recognition of electronic information and / or documents as electronic evidence because the existence of electronic information and / or electronic documents is binding and is recognized as valid evidence to provide legal certainty for the operation of electronic systems and electronic transactions, especially in evidence and matters relating to legal actions. conducted through an electronic system as described above in article 5 paragraph (1) and paragraph (2) of the ITE Law. The ITE Law regulates that there are formal and material requirements that must be met so that Electronic Information and Documents can be used as legal evidence.

The formal requirements are regulated in Article 5 paragraph (4) of the ITE Law, namely that Electronic Information or Documents are not documents or letters which according to legislation must be in written form. Meanwhile, the material requirements are regulated in Article 6, Article 15, and Article 16 of the ITE Law, which in essence, Electronic Information and Documents must be guaranteed its authenticity, integrity and availability. To ensure the fulfillment of the material requirements referred to, in many cases a digital forensic process is needed.

\section{Conclusion}

Based on the provisions of Article 183 of the Criminal Procedure Code, it can be concluded that the Criminal Procedure Code adheres to a system of proof according to law negatively. This means that in the case of evidence, research must be carried out, whether the defendant has sufficient grounds that are supported by means of evidence determined by law (at least two pieces of evidence) and if that is sufficient, then it becomes questionable whether or not the judge's conviction on the defendant's guilt. Apart from that, in Article 294 HIR which contains, no sentence will be sentenced to anyone if the judge is not sure of the Defendant's guilt by means of evidence according to the Law that it is true that a criminal act has occurred and that the accused was the one who committed the act wrong.

Based on Article 5 paragraph (1) and paragraph (2) of the ITE Law, Electronic Information and / or Electronic Documents and / or their printouts are valid legal evidence. The ITE Law regulates that there are formal and material requirements that must be met so that Electronic Information and Documents can be used as legal evidence. The formal requirements are regulated in Article 5 paragraph (4) of the ITE Law, namely that Electronic Information or Documents are not documents or letters which according to legislation must be in written form. Meanwhile, the material requirements are regulated in Article 6, Article 15, and Article 16 of the ITE Law, which in essence, Electronic Information and Documents must be guaranteed its authenticity, integrity and availability.

\section{References}

Andi, Papada. Said Karim, M and Heryani, Wiwie. (2020). Kedudukan Alat Bukti Yang Diperoleh Melalui Teknologi Informasi Dalam Pembuktian Tindak Pidana Informasi Dan Transaksi Elektronik."Jurnal AlQadau: Peradilan dan Hukum Keluarga Islam. 7 (1) . 107-118.

Bakhtiar, H. S., Sofyan, A. M., Muhadar, Soewondo, S. S. (2019). The Essence Of Autopsy In The Criminal Investigation Process. International Journal of Scientific \& Technology Research, 8(10). 9-16.

Chazawi, A. (2006). Hukum pembuktian tindak pidana korupsi: UU no. 31 tahun 1999 diubah dengan UU no. 20 tahun 2001. Bandung: Alumni.

Darwan, P. (1989). Hukum Acara Pidana suatu pengantar. Jakarta: Djambatan.

Hamzah, A. (2008). Hukum Acara Pidana Indonesia. Jakarta: Sinar Grafika.

Harahap, M. Y. (2000). Pembahasan Permasalahan dan Penerapan KUHAP: Pemeriksaan Sidang Pengadilan. Banding, Kasasi, Peninjaun Kembali, Edisi Kedua, Jakarta: Sinar Grafika.

Imron, A., \& Iqbal, M. (2019). Hukum Pembuktian. Tanggerang: Unpam Press.

Kadir, N. K., Judhariksawan, J., \& Maskun, M. (2019). Terrorism and cyberspace: A phenomenon of cyberterrorism as transnational crimes. FIAT JUSTISIA: Jurnal Ilmu Hukum, 13(4), 333-344.

Mansyur, D. M. A., \& Gultom, E. (2005). Cyber Law dan HAKI dalam Sistem Hukum Indonesia. Bandung: Refika Aditama.

Manope, I. J. (2017). Kekuatan Alat Bukti Surat Elektronik dalam Pemeriksaan Perkara Pidana. Lex Crimen, 6(2).

Nur, R., Dharmawati, D., Bakhtiar, H. S., \& Siliwadi, D. N. (2020). Insult and Defamation through Information Technology: Indonesia Perspective. International Journal on Emerging Technologies, 11(4), 373-378

Raharjo, A. (2002). Cybercrime: Pemahaman dan upaya pencegahan kejahatan berteknologi. Bandung: Citra

\footnotetext{
${ }^{1}$ Bakhtiar, H. S., Sofyan, A. M., Muhadar, Soewondo, S. S. (2019). The Essence Of Autopsy In The Criminal Investigation Process. International Journal of Scientific \& Technology Research, 8(10). 9-16.
} 
Aditya Bakti.

Syamsir, S., \& Yetniwati, Y. (2019). Prospek Cyber Notary Sebagai Media Penyimpanan Pendukung Menuju Profesionalisme Notaris. Recital Review, 1(2), 132-146.

Sasangka, H., \& Rosita, L. (2003). Hukum pembuktian dalam perkara pidana: untuk mahasiswa dan praktisi. Bandung: Mandar Maju.

Sainuddin, L. Magassing, A. M. Sakharina, I.K. Bakhtiar, H.S. (2017). Legal Analysis of Crime Terrorism and Counter Terrorism Strategy. International Journal of Advanced Research (IJAR), 5(7), 93.

Sitompul, J. (2012). Cyberspace, cybercrimes, cyberlaw: tinjauan aspek hukum pidana. Jakarta: PT Tatanusa www. hukumonline.com. (2020). Syarat dan Kekuatan Hukum Alat Bukti Elektronik. https://www.hukumonline.com/klinik/detail/ulasan/c15461/syarat-dan-kekuatan-hukum-alat-buktielektronik/ accessed on September 5, 2020.

Law No. 19 of 2016 on Amendments to Law No.11 of 2008. 